\title{
The dependence of the number of shots and rebounds on the change of rules in the top Czech Basketball Men League: A pilot study
}

\author{
PETR HRUSA \\ Department of Leisure and Tourism, Faculty of Informatics and Management, University of Hradec Kralove, Czech \\ Republic
}

\begin{abstract}
Hrusa, P. (2015). The dependence of the number of shots and rebounds on the change of rules in the top Czech Basketball Men League: A pilot study J. Hum. Sport Exerc., 9(Proc1), pp.S302-S307. The research study focused on the dependence of shooting and rebounds on the change of basketball rules that came into effect at the beginning of the season 2014-15. A substantial rule change concerned the offensive rebound. When the team, that controls the ball and shoots on the basket, so that the ball touches the ring, goes on in the offence, this team has only 14 seconds for shooting to go (before the change there was 24 seconds). The aim of the pilot study was to verify the assumption that the rule change will be reflected in a higher number of total shots (2-point and 3-point) and total rebounds (offensive and defensive), and lower total successfulness of shots. The study focused on 2 consecutive seasons. The research sample comprised the total of 256 matches, 128 in the season 2013-14 and 128 in the current season 2014-15. The employed indicators were average values of number of shots and rebounds. Data were collected from official technical score sheets, recorded in the given seasons. Data evaluation was based on both quantitative and qualitative analysis and the results did not support the hypothesis that the basketball rule change would be reflected in a higher number of shots and rebounds. With regard to the fact that this is a pilot study, further research should follow and the findings are to be compared with the data after the end of the current season. Key words: BASKETBALL RULES, SHOTS, REBOUND, BASKETBALL SEASON.
\end{abstract}

\footnotetext{
Corresponding author. Department of Leisure and Tourism, Faculty of Informatics and Management, University of Hradec Kralove, Rokitanskeho 62, Hradec Kralove 3, 500 03, Czech Republic

E-mail: petr.hrusa@uhk.cz

9th INSHS International Christmas Sport Scientific Conference, 4-6 December 2014. International Network of Sport and

Health Science. Szombathely, Hungary.

JOURNAL OF HUMAN SPORT \& EXERCISE ISSN 1988-5202

(c) Faculty of Education. University of Alicante

doi:10.14198/jhse.2015.10.Proc1.18
} 


\section{INTRODUCTION}

The research study deals with the problem of basketball rule change that came into effect at the beginning of the season 2014-15 (from 1st October). There were several changes requested by coaches and responded by International Basketball Federation (FIBA) by basketball rules amendments. Specifically there was adjusting the number of free throws for technical foul of a player, coach or an accompanying person and adjusting the number of time-outs in the second half. In the first place there was substantial change in the time limit for shooting after an offensive rebound. When the team that controls the ball shoots on the basket, so that the ball touches the ring, and then goes on in the offence, this team has only 14 seconds for another shot to go (before the change there was 24 seconds). The rule change was a base to carry out this pilot study, to analyse and compare total number of field shots, rebounds and shooting successfulness within the selected games.

It may seem that in basketball the rule changes occur quite often. Main reason is partly an effort to cohere basic principles with the level of game development in practice, partly an existence of a sort of a compensatory factor that determines what to ban and what to support in further development. . Webb and McClure (2007), Pumr (1987), Janáč (1989), and Trnovský (1992) agree that basketball rules need to stay open to changes in future, to systematic technical and tactical improvement, with regard to a huge increase of interest in this game worldwide. Trnovsky (1992) claims that among factors determining the level of interest in basketball there are: game dynamics, originality, surprise solutions in different game situations, environment, maturity of spectators and many others. As the most important factor determining the level of game development, Trnovský (1992) counts a "human factor". Dobrý (1986), Petera and Koláŕ (1998), Trnovský (1992), Paye and Paye (2001), and Velenský (2008) are consistent in the claim that basketball has never stagnated in development and that it has been in continual progress. Game itself and the individual game skills are reflections of a training process.

In recent research, some authors have concerned the basketball rule change as to change of the distance of 3-point line, which came into effect in 2010. In Euroleague basketball games the results suggested that the effects of the rule change were contrary to trends in recent years (Strumbelj et al., 2013). Montero et al. (2013) detected that the number of 3-point shots was higher after the change. Findings of Hrusa (2014) verified lower number of negative manifestations of players' behaviour in dependence on the number of referees in the top Czech basketball league.

\section{MATERIAL AND METHODS}

The research deals with dependence of shooting and rebounds on the change of basketball rules that came into effect at the beginning of the season 2014-15. A substantial rule change concerned the offensive rebound. When the team, that controls the ball and shoots on the basket, so that the ball touches the ring, goes on in the offence, this team has only 14 seconds for shooting to go (before the change there was 24 seconds). The aim of this pilot study was to verify the assumption that the rule change will be reflected in a higher number of total shots (2-point and 3-point) and total rebounds (offensive and defensive), and lower total successfulness of shots.

\section{Participants}

The basic sample comprised the games of the top Czech Basketball Men League in the consecutive seasons 2013-14 and 2014-15, which were preceding and following the rule change concerning offensive rebound. There were the same 12 teams in the top men league participating in both seasons. In total they 
played 541 games in the season 2013-14, which were all recorded and processed in this study. In the season 2014-15 until the time of data analysis of this pilot study there were held 128 games. Based on this, the intentional selection criterion was set to include the same number of games from the beginning of the preceding season to be analysed and compared. Consequently the total number of games included in this pilot study was 256 .

\section{Measures}

The main methods for data collection were comparative content analysis and synthesis of technical score sheets (TSSs). The TSSs contain data from basketball games, when the selected features are recorded by skilled experts right on the court, based on the method of direct observation. The focus was on 2 individual skills: shooting and rebounds. The employed indicators were absolute frequency of the total of 2-point and 3-point attempted shots, successfulness of the total of 2-point and 3-point shots and absolute frequency of total rebounds, both offensive and defensive.

\section{Procedures}

The problem was solved by an empirical, descriptive and causal research with quantitative and qualitative data analysis. The employed indicators were of number and successfulness of shots and rebounds in the given seasons, 2013-14 and 2014-15, which preceded and followed the rule change. The aim of the research was to verify if the rule change has affected the games, in terms of shooting and rebounds. It was assumed that there will be higher number of 2-point and 3-point shots (hypothesis 1 - $\mathrm{H} 1$ ), lower successfulness of 2-point and 3-point shots (hypothesis 2 - H2) and higher total number of offensive and defensive rebounds (hypothesis 3 - H3) in the season of 2014-15 compared to the preceding season

\section{Analysis}

Data were processed and analysed by quantitative and qualitative analysis. The statistical significance of difference was calculated by $x^{2}(p<0.05)$. In qualitative analysis the results were evaluated according to the criteria referring to substantive difference that could affect course of the game in the given indicators, based on a consensus of expert opinions. The criterion of substantive difference was set by a percentage of minimal difference between the average values counted in the games before and after the rule change: at least $5 \%$ for each of the given indicators (number of shots, successfulness of shooting and number of rebounds).

\section{RESULTS}

Evaluation of the data provided following results: descriptive statistics and the results of statistical $(\chi 2, p<$ $0.05)$ and qualitative analysis of the variables and its indicators. The results are compared between the two seasons 2013-14 and 2014-15, which were preceding and following the rule change regarding the offensive rebound. In this pilot study it was assumed that the rule change will be reflected in shots and rebounds. $\mathrm{H} 1$ focused on an increase in total number of shots (2 and 3-point). $\mathrm{H} 2$ focused on an increase in successfulness of total number of shots (2 and 3-point). H3 focused on an increase in total number of rebounds (offensive and defensive). 
Table 1. Statistical significance and qualitative analysis of total number of shots (2 and 3-point)

\begin{tabular}{|l|c|c|c|c|c|c|}
\hline & $\sum 2013-2014 / 2014-2015$ & $\chi^{2}$ & $\mathrm{H}_{0} / \mathrm{H}_{\mathrm{A}}$ & $\begin{array}{c}\text { Qualitative } \\
\text { criterion }\end{array}$ & $\begin{array}{c}\text { Real value } \\
\text { of difference }\end{array}$ & $\begin{array}{c}\text { Substantive } \\
\text { significance } \\
\text { of difference }\end{array}$ \\
\hline $\begin{array}{l}\text { Total shots (2 and 3- } \\
\text { points) }\end{array}$ & $8310 / 8330$ & 0,02 & $\mathrm{H}_{0}$ & $>5 \%$ & $0,25 \%$ & NO \\
\hline
\end{tabular}

As shown in table 1, there was just a small increase of the total number of field shots after the rule change (H1). The increase in the given periods from the beginning of the seasons, each covering 128 games, was 20 shots (both 2-point and 3-point, counted in total). The difference is very small with regard to the fact that the total shots exceeded 8000 in each of the given seasons. The difference in percentage was $0,25 \%$. It follows that the substantive criterion of relative frequency was not exceeded. The statistical significance, calculated on $p<0.05$, was not confirmed.

Table 2. Statistical significance and qualitative analysis of successfulness of total number of shots (2 and 3point)

\begin{tabular}{|l|c|c|c|c|c|c|}
\hline & $\sum 2013-2014 / 2014-2015$ & $X^{2}$ & $\mathrm{H}_{0} / \mathrm{H}_{\mathrm{A}}$ & $\begin{array}{c}\text { Qualitative } \\
\text { criterion }\end{array}$ & $\begin{array}{c}\text { Real value } \\
\text { of difference }\end{array}$ & $\begin{array}{c}\text { Substantive } \\
\text { significance } \\
\text { of difference }\end{array}$ \\
\hline $\begin{array}{l}\text { Successfulness of } \\
\text { total shots (2 and 3- } \\
\text { point) }\end{array}$ & $44,41 \% / 45,45 \%$ & 0,012 & $\mathrm{H}_{0}$ & $<5 \%$ & $1,04 \%$ & NO \\
\hline
\end{tabular}

Concerning $\mathrm{H} 2$, the percentage of successfulness of total shots increased by $1,04 \%$, as shown in table 2 . The criterion of relative frequency was not exceeded. The statistical significance, calculated on $p<0.05$, was not confirmed.

Table 3. Statistical significance and qualitative analysis of total number of rebounds (offensive and defensive)

\begin{tabular}{|l|c|c|c|c|c|c|}
\hline & $\sum 2013-2014 / 2014-2015$ & $X^{2}$ & $\mathrm{H}_{0} / \mathrm{H}_{\mathrm{A}}$ & $\begin{array}{c}\text { Qualitative } \\
\text { criterion }\end{array}$ & $\begin{array}{c}\text { Real value } \\
\text { of difference }\end{array}$ & $\begin{array}{c}\text { Substantive } \\
\text { significance } \\
\text { of difference }\end{array}$ \\
\hline Total rebounds & $4468 / 4363$ & 0,4 & $\mathrm{H}_{0}$ & $>5 \%$ & $-0,35 \%$ & NO \\
\hline
\end{tabular}


In $\mathrm{H} 3$ it was assumed that there will be higher number of total rebounds in the season 2014-15 compared to the preceding one. However, the results shown (see table 3 ) that the total rebounds decreased. The real percentage value of the difference was $-0,35 \%$ (which equals to 105 rebounds, both offensive and defensive counted in total). The criterion of relative frequency for qualitative analysis was not exceeded. The statistical significance, calculated on $p<0.05$, was not confirmed.

\section{DISCUSSION}

The results suggested that the change of offensive rebound (the 24 second rule) did not influence the number of total shots and rebounds and also did not influence shooting successfulness. It was assumed that the successfulness of the field shots will be lower $(\mathrm{H} 2)$. This was not confirmed. Neither the other hypotheses were confirmed, which may be mutually influenced. The assumptions were built on predicting that lower successfulness would induce more attempted shots on basket, and also more rebounds on both sides. As this is a pilot study as a base for further research, it is suggested to carry out a longer-term study and to verify the assumptions also in other basketball leagues

Apparently basketball is a dynamic game as to development of the rules. Question is how the individual rule changes influence the actual game action, from the point of view of players, coaches or spectators. An example of reaction to the progressive development of the rules was shown by FIBA by change of number of referees (from 2 to 3). This was positively reflected in players' behaviour on the court, as supported with evidence of Hrusa (2014). From a long-term point of view the rule changes were surveyed by Strumbelj et al. (2013) who were engaged in Euroleague teams. Their findings suggested that the effects of the rule change are contrary to trends in the recent years. Similarly to this research, Montero, Vila and Longarela (2013) used a number of shots as an indicator of rule change effect. It concerned the shift of 3-point line (50 cm farther from the basket) in 2010 and it was verified that there was a significant increase in 3-point shots.

In practice the empirical research findings might support the change of the rules in basketball to be reasonable and well-founded. However the problem should be a course to a further research, as discussed above. Complex data are to be analysed and compared at the end of the current season in a sample comprising all the games, after the current season 2014-15 has been finished.

\section{CONCLUSIONS}

The results provided base for discussion concerning efficiency of the change of the rule of 24 seconds for offensive rebound, in basketball in the top Czech men league. The aim of this pilot study was to evaluate the total number of shots and rebounds and successfulness of shooting in comparison of the seasons 2013-14 and 2014-15, preceding and following the rule change. The results indicated that there was not a significant increase of the total number of shots (2-point and 3-point), there was not a significant decrease of total shots successfulness, and there was not a significant increase of the total rebounds (offensive and defensive). However, this is a pilot study, and the problem should be a course to a further research. Complex data are to be analysed and compared at the end of the current season in a sample comprising all the games, after the current season 2014-15 has been finished. 


\section{REFERENCES}

1. Arias, J. L., Argido, F. M., \& Alonso, J. I. (2009). Effect of the 3-point line change on the game dynamics in girls' minibasketball. Research Quarterly for Exercise and Sport, 80(3), pp.502-509.

2. Dobrý, L. (1986). Malá škola basketbalu. Praha: Olympia.

3. Hrusa, P. (2014). Dependence of negative expressions of basketball players' behaviour on the frequency of referees. In: Kinesiology: fundamental and applied kinesiology - steps forward: 7th International scientific conference. Zagreb: Sveučilište u Zagrebu, pp.516-519.

4. Janáč, L. (1989). Basketbal: rozhodovanie $v$ praxi. Bratislava: SVMK.

5. Montero, A., Vila, H. \& Longarela, B. (2013) Influence of changing the distance of the 3-point line in basketball. Journal of Human Kinetics. 22(1), pp.245-248.

6. Paye, B., \& Paye P. (2001). Youth Basketball Drills: 110 Basic to Advanced Drills. USA: United Graphics.

7. Petera, P., \& Koláŕ, P. (1998), NBA: historie a současnost. Praha: Jan Vašut.

8. Pumr, M. (1987). Basketbal pro rozhodčí všech tř́d. Praha: Olympia.

9. Stumbelj, E. (2013). A decade of euroleague basketball: An analysis of trends and recent rule change effects. Journal of human kinetics. 38(1), pp.183-189.

10. Trnovský, I. (1992). Teória a didaktika športovej specializácie: basketbal. Bratislava: Univerzita Komenského.

11. Velenský, M. (2008). Pojetí basketbalového učení pro děti a mládež. Univerzita Karlova: Karolinum.

12. Webb, P., \& McClure, R. (2007). Let the Rules Be the Guide. FIBA Assist Magazine: for Basketball Enthusiasts, 26(3), pp.30-33. 